\title{
The Correlation between Students' Learning Style and English Achievement at SMP Muhammadiyah 1 Gresik
}

\author{
Nur Aza Maulidiyah \\ SMP Muhammdiyah 1 Gresik, East Java, Indonesia \\ Email : nurazamaulidiyah@gmail.com
}

Received: Agust 10, 2020

Accepted: Agust 17,2020

Published: August 9,2020

Doi : http://dx.doi.org/10.30587/jetlal.v4i2.2274

\begin{abstract}
The students have their own model for learning language to reach the goal of learning. Learning style is the way of the students to decide the effective and efficient way to sense, remember, process, and save what they have tried to learn. However, the students of junior high school, especially at eighth grade, they have their own learning style to learn the language, but they have not known yet which learning style that can help them achieve English achievement. Meanwhile, there are four kinds of learning style. Those are converger, concrete, conformist, and communicative learners. This quantitative study wants to investigate whether there is correlation between students' learning style and English achievement. The researcher gave the questionnaire which was adopted from Willing (1988) to the students to find the students' learning style. 25 students of Muhammadiyah junior high 1 Gresik grade $8 \mathrm{~A}$ were given the questionnaire. Then, the researcher gave writing test to 17 students who have converger and concrete learning style to know their English achievement. The result of this study showed the different result with the previous study. The previous study showed that converger and concrete could give impact on students' academic achievement. This study showed that there was no significant correlation between converger learning style and English achievement. On the other hands, the result of concrete learning style has the similar result with the previous study which showed significant correlation between concrete learning style and English achievement since the subject of the study was high school students.
\end{abstract}

Key words: Correlation, Learning Style, English Achievement

\section{Introduction}

In learning English in education program focuses on language skills and components. Brown (200: 232) explained that the language skills include of speaking, listening, reading, and writing, while for language components include of vocabulary, grammar, and pronunciation. In other hands, students should apply those language skills and components in their daily life. The students will find their own model to learn. The model of learning is really needed to reach the goal of learning, especially in learning language. They will use their own model which they feel comfort to learn. Some of them, they like to feel and watch, feel and do, think and watch, and think and do during they learn. All of them are kinds of learning style which is used by the students. Those learning styles can be explained as behavior, attitudes, and factors.

Learning style can be defined as the way for giving stimuli and respond to the students during they learnt (Soghra, Ali, and Mohammad (2013)). In other hands, Ayu (2012) gave explanation that learning style is the way to the students decide the effective and efficient way to sense, remember, process, and save what they have tried to learn. Based on Rajshree (2013) learning style includes of cognitive, affective, social, and psychological behaviors which can set as the indicators of how the students sense, how the students interact with, and how the students respond with their learning environment.

According to Willing (1987) there are four types of learning style. Those are: convergers, conformists, concrete learners, and communicative learners. Lorna (2013) gave the explanation that there are two kinds of approaches which can support students' learning. Those are acquisition learning and formalized learning. Acquisition learning can be called as the contained of learning. In this approach, the students learn something after they finish 
doing the task insensitively. In other hands, formalized learning can be said as the facilitator of learning. In this case, the students aware that what they have learnt is included in learning process and they will reach it later.

Mumtaz (2013) discovered that the students of college who emphasizes on learning style as their strategies in learning process, will get the high score for the test, prior knowledge, and efficiency than those who do not use learning style as their emphasize in learning. Therefore, learning style can be determined the students' academic achievement.

Alireza, Rahil, Habibah, Shafee, and Jafar (2011) explained that there are some factors which can influence academic achievement, such as: behavioral characteristic, psychological factors, namely, attitudes, and self concept. Those factors can be achieved for reaching the academic achievement. In other hands, English achievement is equipped from the result of the language test. Its achievement can be described as communicative as well as linguistic competence. The students' English achievement (overall competence) can be achieved if the students obtained the English test which consists of language skill and components with different evaluation (David, 2011).

Relate to those theories above, learning style is one of important aspect that may determine how successful academic achievement is. However, the students of junior high school, especially at eighth grade, they have their own learning style to learn the language, but they have not known yet which learning style that can help them to achieve English achievement. In this case, there are four kinds of learning style, but, the researcher only chooses two kinds of learning style. Those are concrete learners and converger (analytical learners). Those two types of learning style are chosen, caused this study focused on students' English achievement in writing. The students who have concrete learning style, they like to learn the language in use as communication not the theory and work in group. Besides that, the students who have convergers style, they like to learn independently. They are more confident with their ability. They are more critical. So that, the questionnaires are separated to decide the subject of the students who have concrete and converger learner learning style.

Moreover, the researcher simplifies the focus of students' academic achievement into English achievement because the researcher wants to simplify in specific subject. To know the students' English achievement, the students will get the test in specific skill. In this term, the researcher will give writing test to the students because writing skill can cover the skills in English. Richards and Rinandya (2002) stated that writing is the most difficult skill in learning language which should be mastered. However, Chastain (1988) believes that writing is a fundamental communication skill and a distinct asset in the process of language learning. So, learning language can achieve when we see the learner can compose simple writing text. Here, the researcher avoids getting the English score from teacher because the researcher does not know the validity of the test which is given by the teacher. Here, in this study the researcher tries to analyze between those two things. Those are students' converger and concrete learning style and English achievement. Whether there is relationship between students' converger and concrete learning style and English achievement at Muhammadiyah Junior High School 1 Gresik.

\section{a. Learning style}

Keefe and Ferrell (1990: 59) stated that learning style is a group of cognitive, affective, and psychological characteristic which are as the indicators of how learners sense, interact with, and respond with the environment. Moreover, Brown (2000) stated that learning style is the way the learners sense and process the information in learning process. The choice of learning style is a choice which involves the learners in deciding a condition or situation in their learning process. According to Wen Xu (2011), learning style is constant method of performance which reproduces the fundamental causes of manners. On the other hands, learning style is the connection between attitude and strategy in managing and organizing the information which is implicated in learning process (Nabila, Issam, Jean, and Amar).

Learners prefer to learning method which includes interacting with, taking in, and processing the stimuli (Abbas, 2012). Patryja (2014) claimed that learning style is different with skill, but they still correlate each other in perceiving how the learners use the style in learning to cover their skills. From those definitions of some experts during two a half decades, there are some differences definitions of learning style. Keefe and Ferrell (1990), Brown (2000), and Abbas (2012) have the same definition which define learning style as how the students sense and process the information to interact with their environment. On the other hands, Wen Xu (2011) and Nabila, Issam, Jean, and Amar described learning style as the correlation between attitude and strategy in managing the information during learning 
process. So, it can be concluded that learning style is the variety of learning ways which concern of learning model that is assumed to give the best learning for learners. Learning style is the way the learners feel, remember, process, and keep about what they have tried to learn.

\section{b. The Concept of Learning Style}

Generally, learning style is used in education and training. Slavin (2000) gave simple example to describe about learning style. If someone meets new people and memorizes the name by writing and reading, they belong to visual learners. While if the learners learn by hearing and saying the name, they belong to auditory learners. Learning style refers to individual approach in learning which is based on the learners' preferences. Gregorc (1979: 234) described learning style as different behavior which is used as the indicator of the process how the learners from and adapt to their environment. It also gives the indication how the learners operate their mind in learning. Atkins, Moore, Sharpe and Hobbs (2001) proposed that learners give different respond in learning process because their responds are influenced by their thinking, experience, environment, and current task. All of them refer to individual learner's learning style.

A few decades, there are some variety of learning style and model which have been developed by some experts. According to Coffield, Moseley, Hall, and Ecclestone (2004) in one of effort suggestion from Curry (1983) there are three level of learning style approach. It is called Curry onion's model. The model consists of cognitive personality style, information processing style, and instructional preferences (see Figure 1).

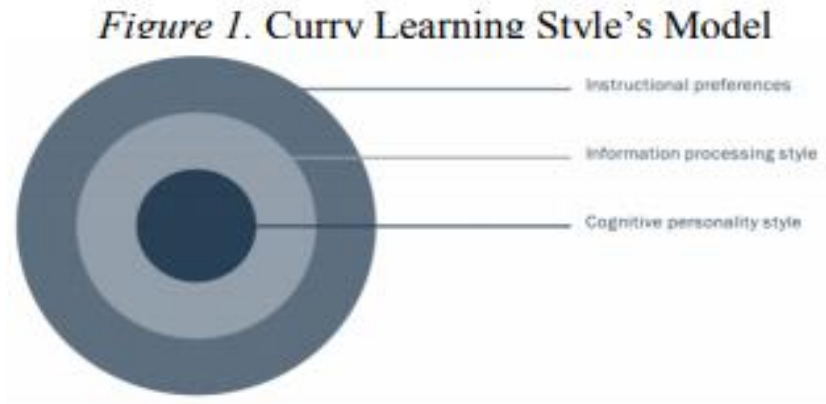

Source: Coffield et al., 2004

\section{c. Learning Style and Cognitive Style}

Some researchers used learning style as the description of cognitive style. James and Gardner (1995) explained that even though learning style and cognitive style can correlate each other, but learning style is used wider in the term of psychology. According to Woolfolk (2001) the difference between learning style and cognitive style, refers to the way to process and organize the information. In addition, Hunsaker (1981) explained that learning style is one of cognitive style parts which refer to the learners when they get and use the information in learning and solving the problem. However, in the term of research, cognitive style is commonly used than learning style.

According to Garity (1985) learning style is commonly used in experimental study to describe the domain of learning such as thinking, recognizing, and remembering. Learning style and cognitive style is different according to Dunn, Dunn and Price (1981). The numbers of style elements are one of the factor to differentiate between learning style and cognitive style (Riding and Cheema, 1991). On the other hands, Hong and Milgram (2000) featured an important different between learning style and cognitive style. They described the cognitive style as the style which is not noticed the learner's effect of interpersonal and intrapersonal characteristic, whereas the learning style gives more attention to the personal social and situational preferences in formal settings.

\section{d. Learning Style Model}

Keith Willing (1987) in Skehan (1998: 247-250) produced learning style model as divided into four types, as following: 
- Convergers: The students who have this learning style, they prefer to work independently. They do not like work in group. In this situation, the students are more confident with their own abilities. They are more critical and can require their learning concept. They tend to be practical.

- Conformists: The students who have this learning style, they prefer to learn language more than using it. They are more dependent in learning language and happy to work in non-communicative classrooms.

- Concrete learners: The students who have this learning style, they enjoy learning something from their own experience. They prefer to learn the language as language use and language communication than as a system. They like playing the games and working in group.

- Communicative learners: The students who have this learning style, they learn the language as language use oriented. They prefer to use language for communicating with other people. They are more comfort practicing the language and like using language outside the class confidently even they make mistake. In this case, they will be happy if the teacher guides their learning process.

However, the researcher chooses the students' learning style categories to categorize the students who have learning style which focus on learning language as language use and communication because the importance of learning language is for communicating each other using international language for transferring their ideas and interacting with the other through English. In addition, the researcher categorizes the students into concrete and converger as the categories which will be correlated into English achievement in writing. On the other hands, the researcher needs to balance between the students' interest through their learning process and the goal of learning.

\section{e. Academic Achievement}

Academic achievement is a crucial in education which is used to indicate the students' competence. According to Joshi and Srivastava (2009), academic achievement is the students' level of competence success which is got from the school-tasks of specific subject. Then, Parveen (2014) defined academic achievement refers to the ability which is got from the test in specific subject which is assigned by teacher.

Moreover, Lawrence and Vimala (2012) stated that academic achievement is a knowledge measurement which is got in formal education which is indicated by test score. In the simple form, the term of academic achievement can be defined as the measurement to reach the successful from teaching and learning process which is given the number as the symbol score. The academic achievement will determine whether the students considered to be success or not and as the consequence, Coetzee (2011:30) also agreed that academic achievement is very important in education.

So, it can be concluded that academic achievement is a tool which is used for measuring of successful in teaching and learning English subject which is got by the students after doing the test. According to the importance of academic achievement in education, it is also needed to learn about the factors which are influenced academic achievement. Abolmaali, et al (2014) mentioned that there are some factors which influence students' academic achievement, those are (1) non-cognitive factors, such as self confidence, self esteem, learning style, and etcetera, (2) cognitive factors, such as intelligence, learning and thinking style, creativity, and etcetera, (3) motivational factors include internal and external factors which students process, (4) quality of school instruction include teaching strategies, school environment, and etcetera, (5) family factors, such as family environment perception and family support perception, (6) socio economic status, such as parents' education and occupation, (7) a combination of different factors (cognitive, emotional, and behavior). Those factors should be known by the learners to achieve their achievement.

\section{f. English Achievement}

In this study, English achievement includes overall competence. This achievement can be said when the students got the English test which consists of language skill, such as: speaking, listening, reading and writing and language components, such as: grammar, vocabulary, and pronunciation with different evaluation, but, this English achievement of this study will be simplified in specific skill, that is in writing skill because the researcher wants to know the students' English achievement from writing to make sure the validity score of the students' English achievement. That is why, the researcher will give the writing test to the students to represent their English achievement. This test is given for knowing the validity of the test. To measure students' English achievement, the 
researcher analyzes the content standard and pass competence standard based on KTSP curriculum which is used in Muhammadiyah Junior High School 1 Gresik.

First, speaking competence, there are 2 standard competences and 4 basic competences. Here, the students should be able to master in using some short expression, such as: asking, giving, and refusing service, thing, admitting and denying facts, information, asking and giving opinion, inviting, accepting, and refusing invitation, offer, agree and disagree, statement, showing care, opening and closing conversation in the telephone, short functional text of advertisement, notice, recount text monolog, narrative text orally, accurately and fluently. Second, the listening competence, there are two standard competences and four basic competences.

The students have to master of responding asking, giving, and refusing service, thing, admitting and denying facts, information, asking and giving opinion, inviting, accepting, and refusing invitation, offer, agree and disagree, statement, showing care, opening and closing conversation in the telephone, short functional text of advertisement, notice, monolog text of recount, narrative text orally, accurately and fluently in listening section.

Third, reading competence, there are one standard competence and two basic competences. Here, the students have to master how the way to read the short text based on the right pronunciation, intonation, stress in word, phrase, and sentence, understanding or identify the contain of short text based on linguistic in advertisement, notice, recount, and narrative text. The last is writing competence consists of one standard competence and two basic competences. Here, the students have to master in identifying, arranging, composing short text advertisement, notice, recount, and narrative text accurately.

\section{Research Method}

a. Research Design and Setting

Since the purpose of this study which has been stated is to find the correlation between students' learning style and English achievement, this study belongs to correlation study. This study uses correlation research design because this study has two variables. They are one independent variable and one dependent variable. This study correlates between independent variable (students' learning style $(\mathrm{X})$ ) and dependent variable (English achievement (Y)). So, this design is applied in this research because the goal of this study is to investigate the relationship between students' learning style and English achievement for the students of Muhammadiyah Junior High School 1 Gresik grade eight.

This study takes the subjects using cluster sampling. The researcher chooses VIII A class as the subject of this study because there is a consideration of students' score record from the previous semester which is shown that VIII A class is the less English achievement rather than another class in eighth grade. It also makes the researcher curious and interest to know the students' learning style which used during learning process. There are 25 students are in VIII A class. In this case, after giving the questionnaire, the researcher simplifies into 17 students for the students who have converger and concrete learning style to give the writing test.

\section{b. Instrument}

There are three instruments which are used in this study in collecting the data. Those are questionnaire, interview, and test.

The questionnaire tends to measure the students' learning style about English subject. Students' learning style questionnaire which is used in this study is adopted from Willing (1988) and it will be translated in Indonesia. The questionnaire which is used in this study concerns on the assessment of learning style's types which are compressed of concrete learners, convergers (analytical learners), communicative learners, and conformists (teacheroriented learners) toward students' English achievement.

Test is used to check the understanding of the students during they learn English. Since the researcher focuses on English achievement, the researcher gives a writing test which is in writing test to check whether the students' English achievement can reach or not. The material in writing test is the material which exists in the students' text book as well. This test includes composing story of their best experience in their life. The students are given a piece 
of paper for composing short story about their holiday. Before composing a short story, students should compose the outline of their story.

The writer chooses structure interview to collect the data from the students in eighth grade in English subject especially in writing activities. The reason of choosing this type is because the writer has already made the questions, so the students just answer the questions from the interviewee. The researcher uses snowball interview sampling to find the interviewees. There are four students of VIII A class who are interviewed. It consists of two students female and two students male. Those four students are chosen based on the observation, they are good interviewee in identifying the problems.

\section{c. Data Collection and Analysis}

The researcher needs variable of both students' learning style and English achievement. Learning style variable is got from the score of learning style's questionnaire which is analyzed by the researcher by totaling the points which are based on the scores given and the scores are interpreted by giving general descriptions of students' learning preferences while English achievement variable is got from writing test which is given by the researcher which is analyzed by the researcher using rubric of writing test. The researcher analyzed it using the rubric.

In this research, the form of the data is continuous/interval and continuous/ratio data. Continuous (interval) data comes from learning style questionnaire and continuous (ratio) comes from English achievement. In this research, the independent variable $(\mathrm{X})$ is continuous (interval) and the dependent variable (Y) is continuous (ratio). Thus, to know the correlation of those two variables, the researcher uses Pearson's r. As Muijs (2004) explanation that if the researcher wants to now the correlation between continuous (interval) and continuous (ratio) variables. The researcher needs to use a rank of correlation coefficient like Pearson's r.

There are two variables in this research, the score of learning style's questionnaire and the score of English achievement. The correlation coefficient vary between -1 and +1 which -1 indicates a perfect negative relationship, +1 indicates a perfect positive relationship, and 0 indicates no relationship.

\section{d. Result}

After analyzing the data all the questionnaires of learning style which had been answered by the students, the researcher accumulated the score of the questionnaire. The researcher classified each student's learning style based on the students' answer in the questionnaire. There were four kinds of students' learning style. Those are converger, conformist, concrete, and communicative learners toward reaching their English achievement. Furthermore, the table below leads the description of students' result of learning style questionnaire of 8th A grade at Muhammadiyah junior high school 1 Gresik. 


\begin{tabular}{|c|c|c|}
\hline No & Student's Name & Learning Style Type \\
\hline 1. & ARR & Converger \\
\hline 2. & AZRA & Converger \\
\hline 3. & AYS & Converger \\
\hline 4. & $\mathbf{A Y}$ & Concrete \\
\hline 5. & AADP & Communicative learners \\
\hline 6. & AD & Conformist \\
\hline 7. & ASR & Communicative learners \\
\hline 8. & ADSP & Conformist \\
\hline 9. & $\mathbf{A N}$ & Conformist \\
\hline 10. & A.JC & Concrete \\
\hline 11. & CA & Concrete \\
\hline 12. & DLPP & Concrete \\
\hline 13. & DDM & Converger \\
\hline 14. & II & Conformist \\
\hline 15. & KNP & Converger \\
\hline 16. & MIRD & Converger \\
\hline 17. & MCP & Converger \\
\hline 18. & MWS & Concrete \\
\hline 19. & NKW & Converger \\
\hline 20. & RAP & Converger \\
\hline 21. & RSS & Conformist \\
\hline 22. & $\mathbf{R P}$ & Conformist \\
\hline 23. & RA & Concrete \\
\hline 24. & SFBS & Concrete \\
\hline 25. & VRA & Converger \\
\hline
\end{tabular}

From the table 4.1 , it could be seen that there were 10 students or $40 \%$ students who had converger learning style, 7 students or $28 \%$ students who had concrete learning style, and there were 6 students or $24 \%$ students who had conformist learning style, the last, there were 2 students or $8 \%$ students who had communicative learners learning style.

Second, for the students who had converger and concrete learning style types, they were chosen to be the subject of this study. There were 17 students or $68 \%$ students who had converger and concrete learning style type. The students who had converger learning style type, they tend to learn the language in use as communication not the theory and work in group. Besides that, the students who had convergers style, they tend to learn independently. They are more confident with their ability. They are more critical. Finally, this study would only correlate between students' who had converger and concrete learning style and English achievement.

The English achievement score of 8th A grade students of Muhammadiyah junior high school 1 Gresik academic year 2015-2016 was obtained from writing test. The writing test score represented the ability of the students in learning English. The writing score was got from three raters. Those were the English teacher, the researcher, and the researcher's partner. The first score came from the English teacher. It could be seen below. 


\begin{tabular}{cccc}
\hline No. & Name & The Score of Writing Test & Result ${ }^{*}$ \\
\hline 1. & AJC & 40 & Fail \\
\hline 2. & ARR & 25 & Fail \\
\hline 3. & AY & 45 & Fail \\
\hline 4. & AYS & 55 & Fail \\
\hline 5. & AZR & 46 & Fail \\
\hline 6. & CA & $\mathbf{8 0}$ & Pass \\
\hline 7. & DDM & 58 & Fail \\
\hline 8. & DLP & 82 & Pass \\
\hline 9. & KNP & 75 & Pass \\
\hline 10. & MCP & 42 & Fail \\
\hline 11. & MRD & 40 & Fail \\
\hline 12. & MWS & 75 & Pass \\
\hline 13. & NKW & 78 & Pass \\
\hline 14. & RA & $\mathbf{8 0}$ & Pass \\
\hline 15. & RAP & 60 & Fail \\
\hline 16. & SF & $\mathbf{8 5}$ & Pass \\
\hline 17. & VRA & 36 & Fail \\
\hline & Total & 1002 &
\end{tabular}

Table 4.2.1 The result of writing test from English teacher

The second score came from the researcher. The score could be seen below.

\begin{tabular}{|c|c|c|c|}
\hline No. & Name & The Score of Writing Test & Result ${ }^{2}$ \\
\hline 1. & A.JC & 50 & Fail \\
\hline 2. & ARR & 30 & Fail \\
\hline 3. & AY & 48 & Fail \\
\hline 4. & AYS & 55 & Fail \\
\hline 5. & AZR & 57 & Fail \\
\hline 6. & $\mathbf{C A}$ & 79 & Pass \\
\hline 7. & DDM & 62 & Fail \\
\hline 8. & DLP & 83 & Pass \\
\hline 9. & KNP & 80 & Pass \\
\hline 10. & MCP & 55 & Fail \\
\hline 11. & MRD & 48 & Fail \\
\hline 12. & MWS & 75 & Pass \\
\hline 13. & NKW & 80 & Pass \\
\hline 14. & RA & 79 & Pass \\
\hline 15. & RAP & 65 & Fail \\
\hline 16. & SF & 90 & Pass \\
\hline 17. & VRA & 45 & Fail \\
\hline & Total & 1081 & \\
\hline 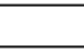 & Average & 64 & \\
\hline
\end{tabular}


achievement $>74$

Table 4.2.2 The result of writing test from the researcher

The third score came from the researcher's partner. The score could be seen below.

\begin{tabular}{|c|c|c|c|}
\hline No. & Name & The Score of Writing Test & Result* \\
\hline 1. & A.JC & 66 & Fail \\
\hline 2. & ARR & 35 & Fail \\
\hline 3. & AY & 65 & Fail \\
\hline 4. & AYS & 44 & Fail \\
\hline 5. & AZR & 39 & Fail \\
\hline 6. & CA & 75 & Pass \\
\hline 7. & DDM & 44 & Fail \\
\hline 8. & DLP & 82 & Pass \\
\hline 9. & KNP & 68 & Fail \\
\hline 10. & MCP & 51 & Fail \\
\hline 11. & MIRD & 41 & Fail \\
\hline 12. & MWS & 60 & Fail \\
\hline 13. & NKW & 75 & Pass \\
\hline 14. & RA & 80 & Pass \\
\hline 15. & RAP & 42 & Fail \\
\hline 16. & SF & 83 & Pass \\
\hline 17. & VRA & 57 & Fail \\
\hline & Total & 1007 & \\
\hline & Average & 59 & \\
\hline
\end{tabular}

*) Fail if the score of English achievement $<75$ and Pass if the score of English achievement $>74$ 
Table 4. 2.3 The result of writing test from the researcher's partner

Those scores from those three raters were accumulated. The accumulation score could be seen on this table below.

\begin{tabular}{|c|c|c|c|}
\hline No. & Name & The Score of Writing Test & Result ${ }^{*}$ \\
\hline 1. & A.JC & 52 & Fail \\
\hline 2. & ARR & 30 & Fail \\
\hline 3. & $\mathbf{A Y}$ & 53 & Fail \\
\hline 4. & AYS & 51 & Fail \\
\hline 5. & AZRA & 47 & Fail \\
\hline 6. & $\mathbf{C A}$ & 78 & Pass \\
\hline 7. & DDM & 55 & Fail \\
\hline 8. & DLP & 82 & Pass \\
\hline 9. & KNP & 74 & Fail \\
\hline 10. & MCP & 49 & Fail \\
\hline 11. & MRD & 43 & Fail \\
\hline 12. & MWS & 70 & Fail \\
\hline 13. & NKW & 78 & Pass \\
\hline 14. & RA & 80 & Pass \\
\hline 15. & RAP & 56 & Fail \\
\hline 16. & SF & 86 & Pass \\
\hline 17. & VRA & 46 & Fail \\
\hline & Total & 1030 & \\
\hline 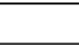 & Average & 61 & \\
\hline
\end{tabular}

Table 4.2.4 The accumulation score of writing test

After analyzing writing score of students of 8th A grade at Muhammadiyah junior high school 1 Gresik academic year 2015-2016, it could be concluded that their ability in achieving English was still low since the average of the students' writing was 61 . From the table 4.2.4, the lowest score was 30 and the highest score was 86 . It also could be seen that some of the students had not passed the standard minimum score yet. It meant that, the accumulation score of writing test that some students got was still below of standard minimum score. In this case, the standard minimum score of learning English which had been determined by the school was 75 .

Table 4.2.4 showed that the students who had passed the standard minimum score were 5 students $(30 \%)$, while the students who had not been passed the standard minimum score was 12 students (70\%). It meant that the ability of the students of 8th A grade was still low in achieving English. Then, the score of writing test was used as the data to be correlated with students' learning style.

\section{e. The Result of Interview}

The result of interview was got from interviewing four students of 8th A grade of Muhammadiyah junior high school 1 Gresik who had good interviewee in identifying the problems. The interview process was done to check the result of the questionnaire as well. In this case, the researcher interviewed two student boys and two student girls. They had converger and concrete learning style. The questions for interviewing the students had been prepared by the researcher. The result of interviewing the students to know their learning style could be seen below:

- $\quad$ Student A (boy):

The first student told that he often used student's book, laptop and LCD, and television as his media to learn English. He liked to work in group because he thought that studying in group was easy to understand the material. On the other hands, he preferred to study inside the classroom because he did not like to study in crowded situation. He liked listening western music to learn new word. Meanwhile, he also liked to study using game and watch movie. He 
liked to get the assignment from the teacher to test their ability and teacher helped him to solve the problem if he felt difficult.

- $\quad$ Student B (boy):

The second students told that he often used student's book, laptop and LCD, television, and worksheet as his media to learn English. He liked to work individual because he could not concentrate if he studied together with his friends, sometimes studying with his friends were very crowded. Moreover, he preferred to study inside the classroom because he liked studying in quite situation. He liked reading story to learn new word. Meanwhile, he also liked to study by watching action movie to study grammar. He liked to get the explanation from teacher to make him more understand in his studying.

- $\quad$ Student C (girl):

The third student said that she often used student's book, laptop and LCD, workbook, and worksheet as her media to learn English. She liked to work individual because she could be more concentrate well. Moreover, she preferred to study inside the classroom because she liked studying in quite situation. She liked reading book to learn new word. Meanwhile, she also liked to study with listening the music to study grammar. She liked to get the assignment from the teacher to test her ability because if it was only listening teacher's explanation, it was boring for her.

- $\quad$ Student D (girl):

The last student said that she often used student's book, laptop and LCD, television, workbook as her media to learn English. She liked to work in group because she thought that it was interesting and she could exchange idea with her friends. Moreover, she preferred to study outside the classroom because she wanted express her English with her environment. She liked listening western music and reading book to learn new word. Meanwhile, she also liked to study by watching western movie. She liked to get the assignment from the teacher to test her ability and teacher helped her to solve the problem if she felt difficult. It could be concluded that students A and D had concrete learning style and the students B and C had conveger learning style.

\section{f. Pearson Product-Moment Correlation}

Pearson product-moment correlation was used since the researcher got the reference from Muijs: 2004 that if the continuous/interval data (learning style questionnaire) and the continuous/ratio data (writing score) were used, it may use Pearson's $r$ formula. Pearson's $r$ was got from SPSS software by inputting both of the data, such as learning style questionnaire score and writing test score in different column based on its variable. The first column was for learning style questionnaire score, and the second column was for writing test score. After that, the researcher calculated both of the scores to know the correlation between students' learning style and English achievement at Muhammadiyah junior high school 1 Gresik grade $8 \mathrm{~A}$. The calculation of the data used correlation coefficient. The result of the data was shown on the table below. 


\section{Correlations}

\begin{tabular}{llrr}
\hline & & Converger & Writingtestscore \\
\hline Converger & Pearson Correlation & 1 & $.187^{* * *}$ \\
& Sig. (2-tailed) & & .605 \\
& $\mathrm{~N}$ & 10 & 10 \\
\hline Writingtestscore & Pearson Correlation & $.187^{* *}$ & 1 \\
& Sig. (2-tailed) & .605 & \\
& $\mathrm{~N}$ & 10 & 10 \\
\hline
\end{tabular}

**) Correlation is significant at 0,01 level (2-tailed)

Table 4.4.1 The result of correlation coefficient

\section{Correlations}

\begin{tabular}{llrr}
\hline & & Concrete & Writingtestscore \\
\hline Concrete & Pearson Correlation & 1 & $.818^{* *}$ \\
& Sig. (2-tailed) & & .024 \\
& $\mathrm{~N}$ & 7 & 7 \\
\hline Writingtestscore & Pearson Correlation & $.818^{* *}$ & 1 \\
& Sig. (2-tailed) & .024 & 7 \\
& $\mathrm{~N}$ & 7 & \\
\hline
\end{tabular}

**) Correlation is significant at 0,01 level (2-tailed)

Table 4.4.2 The result of correlation coefficient

Table 4.4.2 The result of correlation coefficient

From table 4.4.1, the correlation between converger learning style and English achievement was 0.187. In this case, based on Muijs (2004), 0.187 belonged to weak correlation. Here, the correlation coefficient showed weak and positive value. It meant that there was weak and positive correlation between converger learning style and English achievement.

In addition, from table 4.4.2, the correlation between concrete learning style and English achievement is 0.818. Based on Muijs (2004), 0.818 belonged to strong correlation. The correlation coefficient showed positive value. It meant that there was positive and very strong correlation between concrete learning style and English achievement.

Positive value here could be understood that students' converger and concrete learning style and English achievement were in the same direction. It implied that students' learning style could influence their English achievement. Therefore, students who had chosen the appropriate learning style, they would have high in English achievement. It also indicated that students needed to enhance their learning style to increase their English achievement. Meanwhile, for very strong correlation which existed between converger learning style and English achievement and strong correlation which existed between concrete learning style and English achievement could be used as the predictors of students' English achievement. It meant that, the choices of students' learning style could give strong influence to students' English achievement.

So, the correlation of students' converger learning style and English achievement at Muhammadiyah junior high school 1 Gresik was positive and weakly correlated. On the other result of concrete learning style and English achievement at Muhammadiyah junior high school 1 Gresik was positive and strongly correlated.

\section{g. Hypothesis}


Testing Hypothesis of this study was needed to determine whether both of the data had significant correlation each other or not. The hypotheses of this study were $\mathrm{H} 0, \mathrm{H} 1$, and $\mathrm{H} 2$. The null hypothesis (H0) was there is no significant correlation between students' learning style and English achievement $(p=0)$. Meanwhile, the first working hypothesis was there is significant correlation between converger learning style and English achievement $(p \neq 1)$. The second working hypothesis (H2) was there is significant correlation between concrete learning style and English achievement $(\mathrm{p} \neq 1)$. The null hypothesis could not be rejected if $\mathrm{p}$-value (significant correlation) was higher than $\alpha$ (0.05).

Based on the table 4.1.4.1, the p-value of converger learning style and English achievement was 0.605. This was higher than $\alpha(0.05)$. So that is why, the null hypothesis could not be rejected since the p-value was higher than $\alpha$ (0.05). Because the null hypothesis was accepted, so, the first working hypothesis was rejected. It meant that there was no significant correlation between converger learning style and English achievement.

On the other hands, on the table 4.1.4.2, the p-value of concrete learning style and English achievement was 0.024 . This was lower than $\alpha(0.05)$. So that is why, the null hypothesis could be rejected since the p-value was higher than $\alpha(0.05)$. Because the null hypothesis was rejected, so, the second working hypothesis was accepted. It meant that there was significant correlation between concrete learning style and English achievement.

\section{h. Correlation between Students' Learning Style and English Achievement}

From the previous explanation above, the result of coefficient correlation of this study were 0.187 and 0.818 . It meant that there was weak and positive correlation between students' converger learning style and English achievement and there was strong correlation between students' concrete learning style and English achievement of 8th A grade at Muhammadiyah junior high school 1 Gresik academic year 2015 - 2016.

Because of it, positive correlation could be meant that the students who had converger learning style, their learning style could influence their English achievement. Therefore, students who had chosen the appropriate learning style, they would have high English achievement. This case could be happened because the students who had converger learning style, tended to work independently. They did not like to work in group. In this situation, the students were more confident with their own abilities. They were more critical and could require their learning concept. They tended to be practical. Then, for the students who had concrete learning style, they enjoyed learning something from their own experience. They preferred to learn the language as language use and language communication than as a system. They liked playing the games and work in group. Finally, the choices of students' learning style could give strong influence to students' English achievement.

Moreover, the first hypothesis of this study was 0.001 . In the same way, the second hypothesis of this study was 0.038 . It meant that, the first and second hypothesis were lower than $\alpha(0.05)$. So, it could be concluded that there was significant correlation between student's converger and concrete learning style and English achievement at Muhammadiyah junior high school 1 Gresik.

\section{i. Discussion}

Comparing with the result found by the researcher and the finding of another research, the research which had the similar result with this study was conducted by Rajshree (2013) about the relationship between learning style and academic achievement of secondary school students. The subject of this study was 200 students through random sampling techniques from various schools of Nagpur city in Maharashtra state.

Here, the researcher delivered the learning style questionnaire of the students, and then he also gathered academic achievement for all subjects. After that, the researcher analyzed the data. Finally, the result showed that there was positive high correlation between kinesthetic learning style and academic achievement at secondary school students. In the same result from this study was there was strong and positive correlation between student's concrete learning style and English achievement. Another study which is contrary with this study was conducted by Lorna (2013) about the relationship between learning style preferences and academic performance of students.

Subject of this study were all the freshman students who were accepted in trimester of academic year 20122013. The instruments which were used in this study were index of learning style (ILS) questionnaire. Here, the students could fill the questionnaire by accessing internet which the questionnaire was produced by Felder and 
Solomon in 1997. To count the students' achievement, it used grade point average (GPA) and the academic performance would purely be through grade point average in the beginning trimester.

The researcher analyzed the data using SPSS 17.0. One way ANOVA was used to know the differences between preferred style and participants profile variables exist. Pearson product moment correlation coefficients were calculated between learning style and GPA. Finally, it was found that there were no significant differences between learning style preferences and the profile variable of the students. There was no significant correlation between the academic achievement and the learning style preferences of the participants. It had the result with this study that there was no significant correlation between students' converger learning style and English achievement.

In addition, Omid and Somayeh (2012) conducted study about the relationship between EFL learners' learning styles and their L2 achievement. The subjects of this study were 131 EFL students who were selected from high schools in Khansar. Meanwhile, for measuring the students' achievement in learning language, the researcher used general English proficiency test. Then, the result showed that there was low statistical relationship between the learning styles and their foreign language achievement. Its result was similar with the study which was in the first hypothesis. It was showed that there was low correlation between student's converger learning style and English achievement at Muhammadiyah junior high school 1 Gresik grade 8A. From Parveen and Neetu (2011), they used secondary school students toward their academic achievement as the subject of the study. Meanwhile, the subjects of this study were 8th A grade students of Muhammadiyah junior high school 1 Gresik which focused on English subject only.

This difference would influence their different learning style, such as for academic subjects, they tended to use visual, auditory, and kinesthetic as their learning style. Besides, for learning language, they tended to use converger, conformist, concrete, and communicative learners as their learning style. Because the result from the first and the second independent variable was different, so, the study showed the result for first independent variable that there was no significant correlation between student's converger and English achievement. Another result from the second independent variable, showed that there was significant correlation between students' concrete learning style and English achievement. In this case, the students were suggested to choose the appropriate learning style type which was in this study showed that concrete learning style type correlated with the English achievement.

\section{Conclusion}

Two conclusions are drawn based on the analysis and interpretation of the study: (1) The calculation of pearson's product-moment finds the relationship (r) values are 0.187 and 0.818 at $5 \%$ level. It shows that there is positive and weak correlation between students' converger learning style and English achievement and there is positive and strong correlation between students' concrete learning style and English achievement for the students of Muhammadiyah junior high school 1 Gresik at 8th A grade. It means that students' learning style and English achievement sometimes can contribute for each other to make better of English achievement. (2) The result of this study showed the different result with the previous study. The previous study showed that converger and concrete could give impact on students' academic achievement. This study showed that there was no significant correlation between converge learning style and English achievement. On the other hands, the result of concrete learning style has the similar result with the previous study which showed significant correlation between concrete learning style and English achievement since the subject of the study was high school students. 


\section{References}

Airasian, Peter W. and Michael K. Russel. 2008. Classroom Assessment: Concepts and Applications. New York: McGraw Hill High Education.

Albolmali, K., Rashedi , M., and Ajilchi, B. (2014). Explanation of Academic Achievement based on Personality Characteristics Psyco-social Climate of the Classroom and Students'Academic Engagement in Mathematics. Scientific Research. 4. 225-233.

Alireza, Rahil, Habibah, Shafee, and Jafar. 2011. Academic Achievement of Students with Different Learning Styles. Malaysia: Universiti Putra Malaysia, Wawasan Open University, Islamic Azad University.

Anolmaali, K., Rashedi, M., and Ajilchi, B. (2014). Explanation of academic achievement based on personality characteristics psycho-social climate of the classroom and students' academic engagement in Mathematics. Scientific Research. 4. 225-233.

Arikunto, S. 1998. Prosedur Penelitian Suatu Pendekatan Praktek. Jakarta: Rineka Cipta.

Ary, D. 1990. Introduction to Research in Education Fourth Edition. Florida: Holt, Rinehart and Winston Inc.

Ary, D. 2002. Introduction Research in Education Ninth Edition. Florida: Holt, Rinehart and Winston Inc.

Ary, Donald. (2010). Education Research in Education. San Fransisco.

AS. Hornby, Oxford Advanced Learner Dictionary, (Oxford: University Press,1995), p.2

Atkins, H. Moore, M. Sharpe, S \& Hobbs, D. (2001). Learning Style Theory and Computer Mediated Communication. Paper presented at the EdMedia Conference, Tampere, Finland.

Begam, Mumtaz. 2013. The Relationship between Students' Learning Style and Academic Performance in Mara Professional Collage, Malaysia. Malaysia: MARA Profesional Collage.

Belinda HO. 2010. Identifying Students' Learning Style Preferences and Task Design. Hongkong: City University of Hongkong. 
Best, J. W. 1981. Research in Education. New Jersey: Prentice Hall.

Brown, H. Douglas. 2001. Teaching by Principles An Interactive Approach to Language Pedagogy. New York: Pearson Education.

Coetzee, L. R. (2011). The Relationship between Students' Academic Self Concept, Motivation and Academic Achievement at the University of the Free State. South Africa Journal of Education.

Coffield, F., Moseley, D., Hall, E., and Ecclestone, K. (2004). Learning styles and pedagogy in post-16 learning: a systematic and critical review. London, UK: Learning and Research Centre.

Dunn, R., Dunn, K., \& Price, G. (1981). Learning style: research vs. opinion. Phi Delta Kappan, 62(9), 645-646.

Felder, R. and Silverman, L. (2002). Learning and Teaching Styles in Engineering Education. Journal of Engineering Education, 78 (7), 674-681.

Frankel, J. and Wallen, N. 2005. How to Design and Evaluate Research in Education. New York: Mc Graw-Hill Companies Inc.

Gappi, Lorna L. 2013. Relationship between Learning Style Preferences and Academic Performance of Students. Bahrain: AMA International University.

Garity, J. (1985). Learning style basis for creative teaching and learning. Nurse Educator, March/April, 12-16.

Gilakjani, Abbas Pourhosein. 2014. A Match or Mismatch between Learning Styles of the Learners and Teaching Styles of the Teachers. Iran: I.J. Modern Education and Computer Science.

Gregorc, A. (1982). Adults guide to style. Columbia, Conn: Gregorc Associates Inc. ISBN 0934481016

H. D. Brown. 2000. Principles of language teaching and learning (4th ed). White Plains, NY: Longman.

Hong, E., \& Milgram, R. (2000). Homework: motivation and learning preference. Westpost, Connecticut: Bergin \& Garvey.

http://www.kmeljournal.org/ojs/index.php/onlinepublication/article/viewFile/22/64) Hunsaker, J. (1981). The experiential learning model and the learning style inventory: an assessment of current finding. Journal of Experiential Learning and Simulation, 2. 145-152.

Ibtisam, Hussein, and Rasul. 2007. An Analytic Survey of the Learning Style of Students in the Department of English/Collage of Education/Kerbala.University of Kerbala.

Jackson, C. J. (2005). The neuropsychological model of learning and its application to business, education, training, and clinic psychology. Australia: Cymeon. Available from http://www.Cymeon.com.

James, W. \& Gardner, D. (1995). Learning style: implications for distance learning. New Directions for Adult and Continuing Education, (67) 19- 32.

Kaminska, Patryja Marta. 2014. Learning Style and Second Language Education. Cambridge Scholars Publishing. 
Keefe, J., \& Ferrell, B. (1990). Developing a defensible learning style paradigm. Educational Leadership, 48 (2), 27 61.

Kevin Barry and Len King, Beginning Teaching and Beyond 3rd edition, (Sydney: Thomson Social Science Press, 1998), p.498

Lasagabaster, David. 2011. English Achievement and Student Motivation in CLIL and EFL Setting. Spain: University of Basque Country.

Lawrance, A. S. A. \& Vimala, A. (2012). School Environment and Academic Achievement of Standard IX students. Journal of education and instructional studies in the world. 2(3). 210-215.

Muijs, D. 2004. Doing Quantitative Resarch in Education. London: SAGE.

Mulyasa, E. 2007. Kurikulum Tingkat Satuan Pendidikan . Bandung: PT Remaja Rosdakarya.

Nabila, Issam, Jean, and Amar. Analyzing the Relationship between Learning Styles and Navigation Behavior in WebBased Educational System. Algerian \& Frence: (http://www.aabri.com/manuscripts/09281.pdf

Nunan, D. 1991. Language Teaching Methodology. New York: Prentice Hall.

Panjaitan, M. O. (2013). Analysis of Content Standards for English in Junior Secondary School and Senior Secondary School. Jurnal Pendidikan dan Kebudayaan. 19 (1). 140-155.

Parveen, D. (2014). Relationship between Intelligence and Academic Achievement of Secondary Level Students. Global journal for research analysis. 3(3). 35-36.

Patton, M. Q. 2002. Qualitative Research and Evaluation Methods (3rd ed.). Thousand Oaks, CA: Sage.

Petrus-Vancea, A. (2009). Some students learning style particularities. Annal University of Oradea, 16(2), 108-114.

Putri, Ayu Dian Puspayani S. 2012. The Effect of GIST and Learning Style Toward Reading Comprehension of Grade XI Students at SMA Dwijendra Bualu in Academic Year 2011/2012. Singaraja: Ganesha University of Education.

Reinert, H. (1976). On picture is worth a thousand word? Not necessarily. Modern Language Journal, 60(4). 160-169.

Riding, R. \& Cheema, I. (1991). Cognitive styles an overview and integration. Educational Psychology, 11(3), 193215. Doi: 10.1080/0144341910110301.

Riding, R. and Rayner, S. (1999). Cognitive Styles and Learning Strategies: Understanding styles difference in learning and behavior. London, England: David Fulton Publisher Ltd.

Sanavi, Reza Vahdani and Samaneh Tarighat. 2014. Critical Thinking and Speaking Proficiency: A mixed-method Study. Iran: Academy publisher manufactured in Finland.

Sharma, Parveen and Neetu. 2011. A Study of Learning-Thinking Style of Secondary School Students in Relation to Their Academic Achievement. India: Hindu College of Education and Lt.M.S. College of Education.

Slavin, R. (2000). Education Psychology: theory and practice (6th, ed). Boston, MA: Allyn \& Bacon. 
Soghra, Ali, and Mohammad. 2013. Learning Style and Academic Performance of Students in English As A SecondLanguage Class in Iran. Iran: Arak and Lordegan Payamenoor University.

Srivasta, R. and Joshi, S. (2014). Relationship between self concept and self esteem in adolescence. International Journal of Advanced Research. 2(2). 36-43.

Tabatabaei, Omid and Somayeh Mashayekhi. 2012. The Relationship between EFL Learners' Learning Style and Their L2 Achievement. Iran: English Department, Najafabad Branch, Islamic Azad University.

Vaishnav, Rajshree S. 2013. Learning Style and Academic Achievement of Secondary School Students. Nagpur: Chirayu K. C Bajaj College of Education.

Willing, K. (1987). Learning Style in Adult Migrant Education. Andelaide: Adult Migrant Education Program.

Willing, K. 1988. Learning style in adult migrant education, p.106, NCRC.

Woolfolk, A. (2001). Educational psychology (8th, ed.). Boston. MA: Allyn \& Bacon.

Xu, Wen. 2011. Learning Styles and Their Implications in Learning and Teaching. China: College of Foreign Studies of Guilin University of Technology. 